ENTREPRENEURSHIP AND SUSTAINABILITY ISSUES

ISSN 2345-0282 (online) http://jssidoi.org/jesi/

2020 Volume 8 Number 2 (December)

http://doi.org/10.9770/jesi.2020.8.2(50)

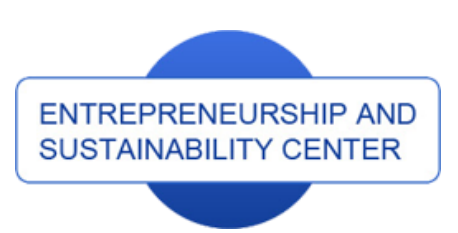

Publisher

$\underline{\text { http://jssidoi.org/esc/home }}$
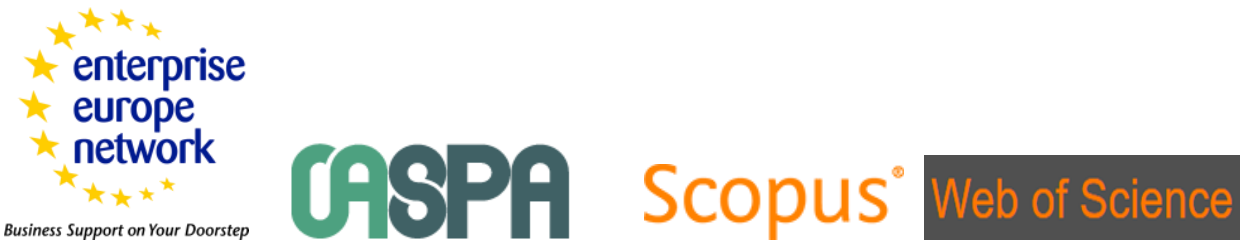

1) Clarivate

Analytics

\title{
THE INFLUENCE OF FOREIGN INVESTORS ON THE DEVELOPMENT OF POLISH ENTERPRISES - A CASE STUDY OF THE BPH BANK
}

\author{
Waldemar Milewicz \\ Warsaw School of Economics \\ al. Niepodlegtości 162, 02-554 Warsaw, Poland \\ E-mail: wmilew@sgh.waw.pl
}

Received 15 March 2020; accepted 30 Sepetember 2020; published 30 December

\begin{abstract}
According to the definition proposed by the Organisation for Economic Cooperation and Development (OECD), foreign direct investment means investment that causes long-lasting relationships. In turn, the latter reflect an interest of an economic entity of one country in an economic entity of a country other than the country of permanent residency of the direct investor. Foreign investors do not only provide production capital in privatized companies, but most of all technical know-how and the know-how on the performed economic activity. They send their specialists who should introduce international standards in daughter companies smoothly and eliminate the previous insufficient level of performance. Due to specific "spreading" of imported know-how the effect of boosted performance also affects domestic enterprises which have not been privatized yet. In this paper, the author will demonstrate the impact of a foreign investor on the development of Bank Przemysłowo-Handlowy in Cracow. A literature review will be used for this purpose, i.e. transaction documentation and post-audit statements of the Supreme Audit Office and delegations of the Ministry of State Treasury. The picture of how Hypovereinsbank has influenced the operation of BPH after the acquisition of shares will be presented as an outcome of this review. It is, thereby, a good example of denying the popular opinion about exploitation of local employees by foreign companies.
\end{abstract}

Keywords: foreign direct investment; know-how; performance

Reference to this paper should be made as follows: Milewicz, W. 2020. The influence of foreign investors on the development of Polish enterprises - a case study of the BPH bank. Enterpreneuship and Sustainability Issues 8(2), 829-839. http://doi.org/10.9770/jesi.2020.8.2(50)

JEL Classifications: F21, L33

\section{Introduction}

According to the definition proposed by the Organisation for Economic Cooperation and Development (OECD), foreign direct investment means investment that causes long-lasting relationships. In turn, the latter reflect an 


\section{ENTREPRENEURSHIP AND SUSTAINABILITY ISSUES}

ISSN 2345-0282 (online) http://jssidoi.org/jesi/

2020 Volume 8 Number 2 (December)

http://doi.org/10.9770/jesi.2020.8.2(50)

interest of an economic entity of one country in an economic entity of a country other than the country of permanent residency of the direct investor (OECD 2008).

Foreign direct investment may be treated as capital investment. It is done outside the country the investor is resident in. Its objective is to undertake economic activity from the ground up or to acquire ownership rights to an existing enterprise, in a scale allowing direct participation in management (Karaszewski 2004).

One can also encounter definitions that present foreign direct investment in a financial approach. This approach defines foreign direct investment as a form of international capital flows (for more see: Globan 2018). It is a response to the differentiation of the level of interest rates in individual countries. Therefore, foreign direct investment is located in a country of a higher interest rate than the one established in the investor's home country (Przybylska 2001).

According to Volker Lederer the import of capital may take place, apart from direct investment, through portfolio investment. According to his interpretation, foreign investor's involvement serves solely the aims of investing capital (without having influence on the financed company) (Lederer 1998). From the investor's point of view, it is the aim of the capital investment that is of prime importance. In turn, direct investment is understood by the said author as taking over an enterprise's activity by the investor in a company that is "foreign" to him" Direct investment in principle may be carried out in two different ways. On the one hand it entails establishing a new company (with or without participation of another local trade partner). On the other, such investment may take place through acquisition of shares in an already existing enterprise (McCulloch 1993).

Private economic operators in transition economies did not have enough savings to purchase shares in state companies at suitable prices. The state does not have the capability to achieve maximization of profit having only domestic investors at its disposal. This is why, from the financial point of view, it seems advantageous to expand the investment circle to include foreign investors (or possibly to carry out privatization only with the aid of foreign investors). Moreover, rapid inclusion of foreign, international in particular, enterprises to the national economy evens out the deficiency in competitiveness between domestic operators (for more about competitiveness see: Zeibote et al. 2019).

Parent companies do not have merchandise that would be competitive on international markets - the reason lies in the lack of know-how, outdated technology or inadequate product quality. Enterprises with foreign participation usually feature a high share of equity, use modern technology and pay above-average remunerations. Based on investment data of foreign companies, it can be concluded that they carry out restructuring more quickly and more intensively than comparable companies with purely domestic participation. This indeed can lead to short-term high unemployment rates. Nevertheless, in a long run, thanks to later investment the development of a company that has been taken over will be more balanced.

As many literature sources show (look it up in references - for example the case of Slovakia), foreign direct investment plays crucial role in given country (Táncošová, 2019; Fabuš et al. 2018). Foreign investors do not only provide production capital in privatized companies, but most of all technical know-how and the know-how on the performed economic activity. They send their specialists who should introduce international standards in daughter companies smoothly and eliminate the previous insufficient level of performance. Due to specific "spreading" of imported know-how the effect of boosted performance also affects domestic enterprises which have not been privatized yet (Dieckheuer 1990).

Since the beginning of the transformation, the Polish government has been aware of the importance of foreign investors in the process of "renewing" the economy. Despite the initial resistance among the population, it was 


\section{ENTREPRENEURSHIP AND SUSTAINABILITY ISSUES}

ISSN 2345-0282 (online) http://jssidoi.org/jesi/

2020 Volume 8 Number 2 (December)

http://doi.org/10.9770/jesi.2020.8.2(50)

noted that bringing in share capital and professional knowledge by foreign investors would serve the modernization of the production and services sector. Foreign models of involvement as companies took different forms. The more production capital and know-how is provided to transition economies, the more foreign companies can enjoy the advantages of a given country such as a low level of wages or good education of the workforce (Wilhelm 1996).

Despite above mentioned advantages of privatization, it can also bring some shortcomings in the long run. In accordance with that opponents of privatisation have condemned it as "selling the family silver to pay the bills". In their opinion, the government, and thus society at large, loses from privatisation, because it gives up a positive stream of cash flows (potential dividends) and puts it in the hands of private buyers (Marques-dos-Santos 2007). Against this background problem of another nature arises. In case of public water companies or rail companies after privatization, private monopoly is created. Therefore there is still need for government regulation, similar to under state ownership (to prevent abuse of monopoly power). Furthermore, privatised businesses are more likely to focus on profit (for more see: Kunitsyna et al. 2018.). This can be bad if the profit-maximising activities of the private business hurt society. If natural monopoly public enterprises are privatized and unregulated in an environment in which property rights are not secure, management is very likely to take an extremely short run view of profit maximization (for more see: Bradburd 1992). The "take the money and run" policies implied by this will yield all the undesirable deadweight loss and distributional consequences of private monopoly and none of the efficiency and service improvement benefits. Private sector managers may have no compunction about adopting profit-making strategies or corporate practices that make essential services unaffordable or unavailable to large segments of the population (Goodman 1991). A profit-seeking operation may not, for example, choose to provide health care to the indigent or extend education to poor or learning-disabled children (Pettinger 2017).

What is also crucial privatization increases income inequality through the decline of contracted workers' wages and benefits. When governments directly provide a service, they often provide living wages and decent benefits to workers. When private companies take control, they often slash wages and benefits in an attempt to cut labor costs, replacing stable, middle class jobs with poverty-level jobs. Reduced worker wages and benefits not only hurt individual workers and their families, but also local economies and the stability of middle and working class communities (Cohen 2016).

Nevertheless, in this paper the author will demonstrate the positive side of privatization and namely the impact of a foreign investor on the development of Bank Przemysłowo-Handlowy in Cracow. A literature review will be used for this purpose, i.e. transaction documentation and post-audit statements of the Supreme Audit Office and delegations of the Ministry of State Treasury. The picture of how Hypovereinsbank has influenced the operation of BPH after the acquisition of shares will be presented as an outcome of this review. It is, thereby, a good example of denying the popular opinion about exploitation of local employees by foreign companies. Furthermore, novelty of my research consists in detailed description of ownership changes in banking with regard to its impact on the both certain company as well as thereby the development of capital market in Poland (for more information about privatization strategies in Poland see: Massmann 2002).

\section{Agreement between the State Treasury of the Republic of Poland and Bayerische Hypo- und Vereinsbank AG - sale of shares of Bank Przemyslowo-Handlowy}

In January 1995, an agreement between the State Treasury of the Republic of Poland and Bayerische Hypo- und Vereinsbank AG was executed for the sale of shares of Bank Przemysłowo-Handlowy and, thus, Bank Przemysłowo-Handlowy in Cracow was privatized. It was decided in the agreement that HVB's performance 


\section{ENTREPRENEURSHIP AND SUSTAINABILITY ISSUES}

ISSN 2345-0282 (online) http://jssidoi.org/jesi/

2020 Volume 8 Number 2 (December)

http://doi.org/10.9770/jesi.2020.8.2(50)

thereof will involve carrying out investment obligations and fulfilling obligations concerning employee matters and other obligations resulting from the agreement (Supreme Audit Office, 2006).

Bayerische Hypo- und Vereinsbank Aktiengesellschaft, headquartered in Munich (now UniCredit Bank AG) is a universal bank. With its subsidiaries it is one of the leading providers of banking and financial services in Germany. It offers a comprehensive range of banking and financial products and services to retail, corporate and public-sector customers, international companies and institutional customers. HVB Group has a well-developed network of branches in Germany, which was modified to accommodate changing patterns of customer behaviour in recent years. In total, HVB Group has 503 offices around the world - 348 of which are HVB offices in Germany.

Bank BPH, in turn, is a Polish universal bank. Until 2008, it was majority owned by UniCredit. In 2008, GE Money Bank took over 89\% of shares and on 31 December 2009, Bank BPH merged with GE Money Bank Polska. At its peak, the bank employed over 10,000 people. In October 2014, the bank's owner, General Electric, revealed it was considering selling the firm. In late 2016, Bank BPH was purchased by Alior Bank. Operations of the two banks merged in early 2017 (Hypovereinsbank 2018).

It terms of the development of the distribution network, Hypovereinsbank supported the strategy of continuing existing main directions of development of BPH's distribution networks. It involved the establishment of small branches. They were located in areas with a high concentration of medium- and high-income customers. Great emphasis was also placed on the development of new, electronic distribution channels (on the basis of the Profile system). The said activity of the strategic investor was reflected in numbers. Thanks to the activity of Hypovereinsbank:

- the number of BPH branches doubled before 2001 to reach the target situation of 400 bank branches,

- cash machines were installed at a pace corresponding to the number of newly-opened branches,

- bank branches in all new voivodship cities were launched,

- the concept of a multi-option bank was implemented.

All of the above facts resulted in BPH becoming a stronger bank in a financial and market angle (i.a. a retail network).

Hypovereinsbank also initiated the Bank's Development Programme. It included a development programme of individual market segments. As a part of it, thanks to the strategic investor:

- banking services for enterprises were improved (customers of Vereinsbank Polska and Hypo-Bank Polska were transferred to BPH; new customers were acquired, including enterprises with foreign capital participation; this was done through the network of BPH branches with the support of Hypovereinsbank);

- an intensive training programme for BPH personnel was implemented;

- leaders of a local character were acquired, mainly in the area of small and medium-sized business;

- existing and new banking products were developed (in particular: financing foreign trade, electronic banking, cash management, leasing);

- retail banking was developed (the standard of customer service was improved); further segmentation of customers was carried out by focusing on 3 groups of customers of the retail market:

a. highest earning customers (private banking), customers),

b. medium- and higher-earning customers (making a living mainly by working for the bank's corporate

c. youngest customers (who are the fundament for creating a future base of high-earning customers)

Moreover, the strategic investor Hypovereinsbank contributed to: 


\section{ENTREPRENEURSHIP AND SUSTAINABILITY ISSUES}

ISSN 2345-0282 (online) http://jssidoi.org/jesi/

2020 Volume 8 Number 2 (December)

http://doi.org/10.9770/jesi.2020.8.2(50)

- the development of BPH's alternative distribution channels (e.g. telephone banking or Internet services); this was done mainly through offering mortgage banking services and distribution of life insurance policies and granting consumer credit,

- the development of the product portfolio.

Furthermore, Hypovereinsbank provided BPH with experience in terms of:

- methods for selling and providing services, marketing and performance management,

- investment banking - Hypovereinsbank provided support to BPH in the development of the following planes of investment banking:

a) capital market operations i.e. services-related organization of issuing debt instruments (bonds) and shares,

b) trading of securities on the secondary market,

c) corporate finance, i.e. consulting at mergers and acquisitions, privatizations and general consultancy for selected customers;

- developing a full package of products related to asset management (including analytical and advisory activity);

- mortgage banking (a mortgage bank was created on the basis of Hypo-Bank Polska, subsidiary to $\mathrm{BPH}$; it became a development platform for BPH's mortgage activity; the strategic investor developed the following in $\mathrm{BPH}$ in this period:

a) a full range of mortgage banking products for corporate and retail customers;

b) distribution channels for mortgage banking products on the basis of BPH's branch network; portfolio);

c) activity in the field of covered bonds (they were a basic instrument of refinancing the mortgage

d) IT systems (they supported the distribution of mortgage banking products and management of the mortgage portfolio).

Moreover, in terms of development and human resources management Hypovereinsbank aided the development of the remuneration system in BPH. This system encouraged employees to work effectively, it increased employee loyalty and created an opportunity of real enhancement of individual earnings (for more see: Androniceanu et al. 2017). The strategic investor also supported the introduction of an intensive training programme. It included general and specialist training for BPH's employees and management carried out in Poland and in renowned international training centres. As a result, thanks to Hypovereinsbank BPH's employees were given the opportunity to participate in various thematic courses (including risk management, mortgage banking, investment banking and treasury activities).

\section{New technological systems in the bank}

After BPH had acquired a strategic investor, consistent implementation of the agreed directions of development was launched in the bank. Consequently, Hypovereinsbank initiated breakthrough undertakings. They significantly contributed to a successive transformation of BPH into a modern financial institution. Owing to this it was able to face the challenges resulting from the ever more competitive market. The following must be included among the said breakthrough undertakings:

- ensuring the opportunity to use PROFILE, a centralized IT system (it was implemented in the central office and throughout the distribution network; at the end of 1998 the system was rolled out in approximately $20 \%$ of bank branches and the finalization of the implementation took place in 1999);

- in terms of IT systems, BPH purchased additional licences; they authorized the use of PROFILE, an integrated banking transactional system; this took place in connection with the development of the network of bank branches and the e-MCI interface; the e-MCI interface served to integrate the Cortex system with the 


\section{ENTREPRENEURSHIP AND SUSTAINABILITY ISSUES}

ISSN 2345-0282 (online) http://jssidoi.org/jesi/

2020 Volume 8 Number 2 (December)

http://doi.org/10.9770/jesi.2020.8.2(50)

PROFILE system in an on-line mode be means of Middleware, a banking system - the strategic investor allocated PLN 1,854,562 for this purpose;

- the strategic investor made capital investment for the development of Cortex; this system served to manage the network of cash machines and to authorize transactions (made by cards issued by the bank); Informix database programmes were purchased for the Cortex system; the strategic investor spent PLN 7,206,739.57 on Cortex;

- the strategic investor undertook capital expenditure for the development of online banking systems; they made it possible to submit instructions which concerned customers' orders in an electronic form; they also allowed for the introduction and development of online banking; electronic and online banking systems made it possible to launch a new additional distribution channel and to expand the array of offered services; Informix database programmes were purchased for the electronic and online banking systems; the strategic investor spent PLN 6,949,339.60 in total on electronic banking systems;

- the strategic investor created a data warehouse, i.e. the Information System for the Management (MIS1); it included reporting sheets obligatory for NBP and sets of basic economic indicators; Oracle's database programme was purchased for the Information System for the Management; the investor also made capital investment for the BPH Brokerage House in terms of programmes and licenses; funds were allocated for developing the following programmes: Makler, POK-Makler, Sponsor, Vivaldi; moreover, Hypovereinsbank purchased a license for a brokerage application PROMAK and rolled it out - in order to boost the efficiency and enhance the quality of customer service; the new brokerage application made it possible to adapt the BPH Brokerage House system to cooperation with a new stock exchange system (SES) introduced by the Warsaw Stock Exchange; the investor purchased an online customer service system of the vIBank Norkerage House and a database programme Informix for the PROMAK application; the costs incurred by the strategic investor for programmes and licences for the BPH Brokerage House amounted to PLN 2,701,428.69;

- as regards Kondor +, Hypovereinsbank purchased rights to use this system; it also undertook capital expenditure for the implementation and development thereof - the system served to register, monitor and manage risk and to control counterparty risk broken down into individual products; the strategic investor purchased Sybase, a database system, for Kondor +; PLN 5,845,466.86 in total was spent on the Kondor + system;

- in the matter of the Middleware system, Hypovereinsbank purchased utility software for BPH; this enabled the creation of a system which integrated external IT systems with a transaction system; the strategic investor spent PLN 5,085,468.99 in total on the Middleware system;

- Hypovereinsbank purchased and rolled out the Imex system; it served to support the processing of documentary operations (documentary collection, letter of credit); the strategic investor spent PLN 520,432.13 in total on the Imex;

- Hypovereinsbank purchased a licence for and rolled out application software ELBA 24; this provided communication between the server operating bank balance printers and the transaction system; the strategic investor purchased ProTopas and ProView system software; it was indispensable in building the functionality of the self-service transaction terminal; it was to allow the performance of financial services; the strategic investor spent PLN 1,057,815.10 in total on the ELBA 24 application software;

- Hypovereinsbank purchased the MySAP.com system for human resources management in BPH; the strategic investor spent PLN 840,723.45 in total on the MySAP.com system;

- when it comes to reporting systems, Hypovereinsbank purchased and made capital investment for the development of computer (system and application) software for handling reporting to NBP and other reporting (including reporting to the strategic investor); the strategic investor spent PLN 3,054,749.50 in total on reporting systems;

- as regards other systems, Hypovereinsbank purchased other computer programmes for BPH's internal needs (application and database software); the strategic investor spent PLN 3,240,002.41 in total on other systems;

- in terms of back-up system centres, Hypovereinsbank undertook capital expenditure for building backup centres for BPH's computer systems; these centres operated under the control of the LN and Unix operating 


\section{ENTREPRENEURSHIP AND SUSTAINABILITY ISSUES}

ISSN 2345-0282 (online) http://jssidoi.org/jesi/

2020 Volume 8 Number 2 (December)

http://doi.org/10.9770/jesi.2020.8.2(50)

systems and for the Profile System, and also for the system of creating back-up copies; the strategic investor spent PLN 8,370,093.41 in total on back-up system centres;

- in the matter of computer systems of BPH's head office, Hypovereinsbank made investments in expanding servers which worked for the LN and Unix systems; moreover, it introduced and rolled out the Windows IT application in central management of work stations in BPH S.A.'s branches as well as Help-Desk management systems and a central archiving system; the strategic investor spent PLN 22,613,287.87 in total on the head office's computer systems;

- Hypovereinsbank purchased licences for servers and work stations as well as office suites, system and utility software; the strategic investor spent PLN 23,776,642.58 in total on the licences;

- Hypovereinsbank undertook capital expenditure concerning a technological merger; it was associated with a key stage of integration of BPH S.A. with PBK S.A.; it involved combining IT systems of both banks; as a result, the integration of the IT systems allowed customers to use a comprehensive product offer in any of the 500 or more bank branches; the technological merger expenditure amounted to PLN 479,812.34

- the remaining investment expenditure was undertaken by the strategic investor for a central printing office; due to the roll out of the centralized PROFILE system it became necessary to ensure the technical infrastructure to service the entire bank network (printing bank statements) - the strategic investor allocated PLN $7,259,354.98$ for this purpose.

- Hypovereinsbank, the strategic investor, allotted further investment expenditure for the "Cherry Business Park"; the investment involved the preparation of rooms for the bank's head office units located in Warsaw; it was connected with the introduction of organizational changes in BPH - PLN 1,724,159.88 was set aside for this project.

- Hypovereinsbank also made capital investment associated with ensuring adequate technical infrastructure; the new infrastructure became an element of restructuring the back-office centre and the server room - the strategic investor allocated PLN 12,356,600.47 for this project.

- Hypovereinsbank undertook investment expenditure for regional cash centres; the investments made were a consequence of outsourcing cash settlement to the company Międzybankowe Centrum Gotówki Sp. z o.o.; it entailed the development of an adequate technical infrastructure - the strategic investor allotted PLN $6,325,701.51$ for this project.

\section{New banking systems in the company}

Moreover, the strategic investor's significant contribution to the development of BPH is evidenced by the following facts:

- the implementation by Hypovereinsbank in BPH in 1999-2000 of online banking for retail customers and customers from the group of small enterprises;

- adoption by BPH S.A.'s Supervisory Board of the "BPH S.A.'s development strategy for 2000-2004"; it outlined direction of development on individual market segments - retail banking, corporate banking, international markets and mortgage banking; together with the adoption of the new strategy, the strategic investor changed management structures of the bank's head office; it introduced an organization system within it oriented towards individual market segments; moreover, Hypovereinsbank implemented a new information system for the management (MIS-1), a new system of controlling and principles of budgeting and managing financial risk;

- Hypovereinsbank rolled out a Call Center project in BPH; to this end, it established a specialised limited liability company Centrum Bankowości Bezpośredniej; beginning in June 2001 it started offering telephone services integrated with a bank account; the strategic investor launched the sale of bank products and services through a specialised telephone centre (Call Center) - the strategic investor budgeted PLN 13,486,720.79 for this purpose;

- Hypovereinsbank invested in the development of technical infrastructure (as a consequence of the development of distribution channels); it expanded the technical facilities of the bank's head office, server room 


\section{ENTREPRENEURSHIP AND SUSTAINABILITY ISSUES}

ISSN 2345-0282 (online) http://jssidoi.org/jesi/

2020 Volume 8 Number 2 (December)

http://doi.org/10.9770/jesi.2020.8.2(50)

in particular; it expanded (central and branch) servers of the Central System and the Symetrix matrix for the Central System and purchased a tape library for its back-up - the strategic investor allotted PLN 26,604,933.23 for this purpose;

- Hypovereinsbank expanded the WAN and LAN ICT networks; it developed ICT systems and security of data sent through the network - the strategic investor allocated PLN 8,948,690.00 for this purpose;

- the development of a new type of bank branches, opened on attractive local markets (2001-2002) - as part of the approved development strategy for BPH S.A.'s branches Hypovereinsbank created 71 new ones; they were opened on the most attractive local markets, mainly in the south of the country and on the territory of the Warsaw conglomeration; in 5 cases the investor adapted the facilities infrastructure to the existing organizational structure; it opened 27 corporate offices (corporate centres); what is more, it created corporate banking macroregions and retail banking macro-regions - they were the bank's organizational units superior to branches; Hypovereinsbank built and modernized structural cabling in branches; it also undertook expenditure for the ICT system, network devices, computer and ICT equipment;

- Hypovereinsbank installed self-service devices (cash machines and bank balance printers); it also created self-service areas in all newly opened banking centres; the objective of this process was to streamline customer service and to lower costs (for more about cost efficiency in banking system see: Tvaronavičienè et al. 2018); the strategic investor allocated PLN 22,690,444.08 for this purpose;

- Hypovereinsbank restructured the back office; it outsourced cash settlement to a separate company Międzynarodowe Centrum Gotówki Sp. z o.o.; it also recapitalized BPH's subsidiaries; they provided specialized financial services e.g. in terms of mortgage banking and leasing (2001).

In the matter of marketing and training of $\mathrm{BPH}$ personnel the following actions were undertaken by the strategic investor:

- the project of regionalization of BPH S.A.'s branches - 4 sales management regions were created; decentralization of decisions took place owing to this and conditions for flexible management of the network of branches were created;

- the concept of organization of specialist teams for individual customer service in branches - 3 teams were appointed in the structure of branches, specializing in mass, medium-affluent, affluent and small business customer service;

- the Consumer Finance project and the BIKE project - concerned BPH S.A.'s cooperation with Norisbank in terms of the sale of credit and retail loans;

- Hypovereinsbank's cooperation with BPH in organizing a contest for customer advisors; it involved the sale of Sez@m internet accounts along with organizing prizes for the winners (a trip to Germany);

- the customer segmentation project - held with constant participation of Hypovereinsbank AG's representative in the working party; an ABS-type segmentation project was being prepared within each customer group;

- marketing plan - Hypovereinsbank AG worked together with BPH in the matter of planning, organizing and outlining the schedule of advertising campaigns; moreover, both entities defined shared product priorities, target markets and the form of internal communication (including a retail service); in accordance with the new concept six promotional campaigns were organized;

- the concept of direction of the development of the retail product price policy - Hypovereinsbank outlined the direction for the development of this policy through: discussing the issues of assignment of price competence, basing the interest rate for retail customers on the market rate, introducing periodically adjusted interest rates for retail customers and the fees and commissions tariff;

- Insurance Cooperation Project - Hypovereinsbank introduced the sale of insurance in the BPH S.A. network and included insurance in bank products;

- small-enterprises project - Hypovereinsbank adopted a strategy for the small-enterprises segment; it focused its action on managing sales and continuation of training programmes for advisors as well as further development of electronic banking;

- Hypovereinsbank organized seminars for directors of branches in Zakopane, Szczyrk and Rytro; 


\section{ENTREPRENEURSHIP AND SUSTAINABILITY ISSUES}

ISSN 2345-0282 (online) http://jssidoi.org/jesi/

2020 Volume 8 Number 2 (December)

http://doi.org/10.9770/jesi.2020.8.2(50)

Hypovereinsbank's transfer of banking technology was also significant in this aspect. It entailed working within the framework of the Integration Project. Thus, the strategic investor performed a transfer of know-how to $\mathrm{BPH}$ as regards:

- managing credit risk of corporate and retail banking;

- management in terms of investment banking, property financing;

- financial management;

- banking and IT technology;

- bank processes (Report, 2002).

\section{Conclusions}

Thanks to the literature review of BPH's transaction and post-transaction documentation (post-audit reports of the Supreme Audit Office) the author came to a few interesting conclusions. After purchasing shares of the aforementioned bank, Hypovereinsbank fulfilled investment obligations laid down in the purchase agreement. It did so by bringing in know-how in the form of organized training programmes, technologies, organizational methods, etc. Therefore, the foreign investor's direct contribution to the qualitative development of BPH was presented (this contribution was demonstrated in the study by cash sums spent by the investor on individual areas of operation, created branches, introduced computer programmes, etc). Summing up, the literature review of the documentation related to the share purchase transaction demonstrated a positive influence of a foreign investor in a Polish bank and thus was an example of the denial, mentioned in the beginning, of a common opinion of exploitation of local employees by foreign companies.

\section{References:}

Androniceanu A., Krajčík, V. 2017. Integrated performance management system in a globalized organization. Conference: Finance and performance of firms in science, education and practice, 26-27 April, 2017, Zlin, Czech Republic, Proceedings of the 8th International Scientific Conference Finance and Performance of Firms in Science, pp. 30-43. ISBN 978-80-7454-653-2.

Bradburd, R. 1992. Privatization of Natural Monopoly Public Enterprises: The Regulation Issue. New York: Published by Review of Industrial Organization, p. 38. https://doi.org/10.1007/BF01027074

Cohen, D. 2016. How privatization increases inequality. Oakland: Published by In the Public Interest, p. 4.

Dieckheuer, G. 1990. Die Bedeutung ausländischer Direktinvestitionen für Beschäftigung, Struktur, Wettbewerbsfähigkeit und Wachstum von Volkswirtschaften - dargestellt am Beispiel der Bundesrepublik Deutschland 1950-1990. Volkswirtschaftliche Diskussionsbeiträge, no. 131. (The importance of foreign direct investment for employment, structure, competitiveness and growth of economies - illustrated by the example of the Federal Republic of Germany 1950-1990. Economic Discussion Contributions, no. 131.) Münster: Published by Westfälische Wilhelms-Universität Münster, p. 19.

Fabuš, M.; Csabay, M. 2018. State aid and investment: case of Slovakia. Entrepreneurship and Sustainability Issues 6(2): $480-488$. http://doi.org/10.9770/jesi.2018.6.2(1)

Globan, T. 2018. From Capital Surges to Capital Drought in A Small Integrated Economy - Lessons from Croatia. Transformations in Business \& Economics 17(1 (43)): 192 -215

Kunitsyna, N., Britchenko, I., Kunitsyn, I. 2018. Reputational risks, value of losses and financial sustainability of commercial banks. Entrepreneurship and Sustainability Issues 5(4): 943-955. http://doi.org/10.9770/jesi.2018.5.4(17)

Goodman, J. B., Loveman, G. W. 1991. Does Privatization Serve the Public Interest? Harvard Business Review, November - December 1991. https://hbr.org/1991/11/does-privatization-serve-the-public-interest

Hypovereinsbank AG, Annual Report 2018 


\section{ENTREPRENEURSHIP AND SUSTAINABILITY ISSUES}

ISSN 2345-0282 (online) http://jssidoi.org/jesi/

2020 Volume 8 Number 2 (December)

http://doi.org/10.9770/jesi.2020.8.2(50)

Karaszewski, W. 2004. Bezpośrednie inwestycje zagraniczne. Polska na tle świata. (Foreign Direct Investment. Poland against the background of the world) Toruń: Published by Dom Organizatora, p. 19.

Lederer, V. 1998. Zur Transformation mittel- und osteuropäischer Betriebe: ein Vergleich ostdeutscher, polnischer und bulgarischer Betriebe auf qualitativ-empirischer Grundlage (On the transformation of Central and Eastern European enterprises: a comparison of East German, Polish and Bulgarian companies on a qualitative-empirical basis). München und Mering: Published by Rainer Hampp Verlag, p. 57.

Marques-dos-Santos, Jose E. 2007. The Long-Run Fiscal Impact of Privatisation: An empirical assessment of the Brazilian experience. p. 2. https://pdfs.semanticscholar.org/6d6c/02656e443ececc6d2917a86dc358001d5db3.pdf

Massmann, E. 2002. Alternative Privatisierungsstrategien in MOE-Staaten: eine Analyse unterschiedlicher Verfahren im Hinblick auf ihre Anwendung am Beispiel der Republik Polen (Alternative privatization strategies in CEE countries: an analysis of different procedures with regard to their application using the example of the Republic of Poland). Köln: Published by Josef Eul Verlag.

McCulloch, R. 1993. New Perspectives on Foreign Direct Investment, in Froot K.A., Foreign Direct Investment, Chicago: Published by University of Chicago Press, p. 43-45.

OECD Benchmark Definition of Foreign Direct Investment, Fourth Edition 2008, p. 48.

Pettinger, T. 2017. Advantages and problems of privatisation. https://www.economicshelp.org/blog/501/economics/advantages-ofprivatisation/

Protocol from an audit carried out by the Supreme Audit Office in the Delegation of the Minister of the State Treasury in Cracow in the period between June and September 2005 on the strategic investor Bayerische Hypo- und Vereinsbank AG's fulfilment of non-price obligations laid down in an agreement executed on 22 October 1998, April 2006, p. 2.

Przybylska, K. 2001. Zagraniczne inwestycje bezpośrednie jako podstawowa forma ekspansji gospodarczej transnarodowych korporacji (Foreign direct investment as the basic form of economic expansion of transnational corporations). Kraków: Published by Zeszyty Naukowe Akademii Ekonomicznej w Krakowie, no. 585, p. 12.

Report on the fulfilment of investment obligations laid down in article 4 of the agreement for the purchase of 4,316,670 shares of Bank Przemysłowo-Handlowy Spółka Akcyjna, Warszawa, 2002, pp. 2-3, 9.

Táncošová, J. 2019. The role of foreign direct investment in the economy of Slovakia, Entrepreneurship and Sustainability Issues 6(4): 2127-2135. http://doi.org/10.9770/jesi.2019.6.4(40)

Tvaronavičienè, M., Masood, O., Javaria, K. 2018. Preconditions of the eurozone economic security: how to overcome liquidity risk and cost inefficiency in leading banks of UK and Germany. Polish Journal of Management Studies 18(1): p. 418-427.

http://doi.org/10.17512/pims.2018.18.1.31

Wilhelm, M. 1996. Gründe für Direktinvestitionen (Reasons for direct investment), in: Ifo Schnelldienst 7 - 8/1996, p. 29.

Zeibote, Z., Volkova, T., Todorov, K. 2019. The impact of globalization on regional development and competitiveness: cases of selected regions. Insights into Regional Development 1(1): 33-47. https://doi.org/10.9770/ird.2019.1.1(3) 


\section{ENTREPRENEURSHIP AND SUSTAINABILITY ISSUES}

ISSN 2345-0282 (online) http://jssidoi.org/jesi/

2020 Volume 8 Number 2 (December)

http://doi.org/10.9770/jesi.2020.8.2(50)

Waldemar MILEWICZ is assistant professor at Warsaw School of Economics (Department of Research on the German Economy). He gives lectures and exercises in the following subjects: "International economic relations", "Microeconomics", "Internationalization of the firm". Research interests: capital markets, finance.

ORCID ID: orcid.org/0000-0002-8652-6307

Make your research more visible, join the Twitter account of ENTREPRENEURSHIP AND SUSTAINABILITY ISSUES: @Entrepr69728810

Copyright (C) 2020 by author(s) and VsI Entrepreneurship and Sustainability Center This work is licensed under the Creative Commons Attribution International License (CC BY).

http://creativecommons.org/licenses/by/4.0/

C. (i) Open Access 